Title: Politicising the Psychology of Social Class: The relevance of Pierre Bourdieu's habitus for psychological research

Authors: Bernhard Wagner and Kenneth McLaughlin

Address for correspondence: Manchester Metropolitan University, 799 Wilmslow Road, Didsbury, Manchester M20 2RR 


\title{
Title: Politicising the Psychology of Social Class: The relevance of Pierre Bourdieu's habitus for psychological research
}

\begin{abstract}
In this paper, we discuss what Pierre Bourdieu's concept of habitus can add to psychologically informed debates around social class. We argue that habitus offers a way of coming to terms with the complexity and different dimensions of social class. For Bourdieu, habitus conceptualises the internalisation of social structures, how the "outer" becomes the "inner". This distinct psychological question is critical for Bourdieu's "psychoanalysis of the social". We argue that Bourdieu's habitus ties in with psychologically informed views on classed existence, but can also function as a tool to further psychological studies by suggesting a broader focus and pointing to aspects that tend to be underrepresented in mainstream psychological research, and that are also difficult to dissect from a psychological vantage point. In particular, questions of structural (power) inequalities and their reproduction on a communal as well as on an individual level are at the core of Bourdieu's habitus concept, but these are often absent from contemporary class analysis. Finally, we argue that for all its complexity, the habitus concept can inform research on a practical level by enabling exploration of the complexity and messiness of the classed nature of everyday experience.
\end{abstract}

Bourdieu, Social Class, Habitus, Inequality

\section{Introduction}

Pierre Bourdieu's work will be familiar to most within the social sciences, in the English-speaking world at least. However, it appears that his social theory is only partly received within much mainstream social research. For example, whereas his theory of forms of social capital has made an impact in sociological, psychological and educational research, his concept of habitus can, at times, be given less attention within such disciplines. As we will argue in the following, this is regrettable for a number of reasons as the habitus concept is of central importance in Bourdieu's oeuvre and is necessary to understand concepts like the aforementioned forms of social capital.

There are a number of contributions that aim to further the psychological foundation of the habitus concept and apply it to issues of interest to psychological research. Lizardo (2009) for instance analyses internalisation as a process of learning with regards to the related neuropsychological processes, and elsewhere argues that the cognitive origins of habitus are at times overlooked (Lizardo, 2004). These are valuable contributions insofar as they counter the tendency to equate internalisations with socialisation. In this paper we will argue that Bourdieu's understanding of the formation of habitus is neither reducible to individual cognitive processes nor can it be assumed to be a purely 
collective process: to put it simply, internalisation in a Bourdieusian sense is how the individual translates their material living conditions into cognitive and unconscious structures - how the social becomes embodied. As Stam (2009, p. 708) shows, psychological research has applied the habitus concept in a multitude of ways ('from the 'habitus of hygiene', the 'erotic habitus', the 'military habitus' to the 'dot-com habitus'") and not all of those can necessarily be seen as following Bourdieu's original concept in terms of intention, meaning and scope. A shortened and superficial interpretation of Bourdieu's work is at risk of producing ahistorical and detached descriptions of the social world or of individual characteristics that ignore and negate Bourdieu's political claims. It is, however, equally problematic to use Bourdieu's theory of forms of capital without locating it in his wider theory and without relating forms of capital to the habitus. Below, we first outline our main concerns on a general, theoretical level and then relate them to a couple of empirical examples, specifically the concepts of empowerment and work stress, which we will argue illustrate the way much of contemporary psychology and related disciplines help frame the habitus in such a way that (classed) power relations are to a great extent unconsidered.

Forms of capital cannot be understood in a meaningful way if not seen in connection to specific fields of the social world. This is probably most obvious with regards to social capital that cannot be dissociated from actual connections and interactions in a specific field. However, other forms of capital like cultural capital cannot be regarded as of essential usefulness and worth, they only gain value if legitimised and therefore validated in related social fields. The relationship between field and capital is a reciprocal one and therefore it is not only the respective fields that validate capital; forms of legitimate capital also structure social fields. Bourdieu's theory of forms of capital proved particularly popular in educational research (Dumais, 2002). If applying Bourdieu's forms of capital to educational contexts, we would argue that it is vital to remember that educational institutions not only validate certain kinds of knowledge and skills, but are themselves shaped by the force of already legitimised social and cultural capital.

Bourdieu's model offers an approach that combines different dimensions of social classification and allows us to analyse their interrelatedness. Therefore the habitus concept is an essential addition to the theory of forms of capitals as it locates these differences historically, politically and in direct relation to the reproduction of power. Furthermore, the habitus concept is very valuable in exploring the interconnectedness of structural relationships and individual characteristics. Of course, Bourdieu's forms of capital cannot be reduced to individual traits, but in the habitus concept this link is developed with regards to the effects of such traits on individual and collective consciousness. The habitus concept furthers and deepens the understanding of the reproductions of social inequalities and is therefore of particular relevance to the aforementioned educational research. In the following we demonstrate that this is equally true for research areas that are traditionally located in the psychological field. 
The habitus concept is of particular interest to such disciplines as sociology, education, social work and psychology as it attempts to bridge the division of labour between the disciplines, a division that has not always proven helpful in the past (Bourdieu \& Wacquant, 1992). It offers a methodology to discuss the interplay between individual, collective and structural aspects of class divisions and is therefore, as a research tool intrinsically political. Using the concept of habitus as a basis for analysing the social world puts structural power relations and their reproduction into focus and problematizes them on a fundamental level.

Habitus is a concept that is often overlooked perhaps due to its perceived vagueness and complexity. Putting it into practice is challenging insofar as it necessarily involves a rather broad perspective that aims to grasp the multidimensionality of social (power) structures that are rather elusive and problematic to express empirically. Things are further complicated by the fact that habitus is a way of analysis, and hence a method, as well as a descriptive term that depicts class-specific internalisations and their effects both on an individual and collective level. We aim to offer a way of disentangling these complexities and making the habitus both conceptually and practically useful, and also demonstrate how the habitus concept can be particularly beneficial as an underpinning of psychological explorations of social class.

We argue that Bourdieu's habitus ties in with psychologically informed views on classed existence, but can also function as a tool to further psychological studies by suggesting a broader focus and pointing to aspects that tend to be underrepresented in mainstream psychological research and that are difficult to dissect from a psychological vantage point. In particular, questions of structural (power) inequalities and their reproduction on a communal as well as on an individual level are at the core of Bourdieu's habitus concept, but these are often absent from contemporary class analysis. The concept of habitus aims to explore the dynamic and reciprocal relationship of individuals, social classes and the hierarchically structured social as a whole. Finally, for all its complexity, we argue that the habitus concept can inform research on a practical level by enabling exploration of the complexity and messiness of the classed nature of everyday experience.

\section{Social Space and Social Class}

Before we explore the habitus concept and its foundation in, and links with, psychological theory, we briefly want to introduce Bourdieu's understanding of social class. We believe this is necessary as a conceptual foundation and also to set the scene with regards to Bourdieu's characteristic interpretation of the relationship of the individual and the social as well as his conception of conscious and unconscious dimensions of social class. 
Bourdieu's understanding of social class is clearly based on Marxist and Weberian ideas and also on a critical examination of Althusser's (1971) structuralism. In the following, we try to demonstrate how Bourdieu's concept of social class links two central dimensions of class analysis: economic structures and social manifestations of inequality. We will argue that a Bourdieusian class analysis offers insights into the subtleties, complexities and unconscious psychological aspects of social class without turning its back on the material basis of inequality.

Bourdieu regards the social world as a multi-dimensional and structured space. He "breaks with Marxist theory" (Bourdieu \& Thompson, 1991, p. 239) to emphasise relations over structure. This means that for Bourdieu the focus is much more on the relations within a social space than on the concrete specifics of social groupings. Whether this constitutes an actual "break" with Marxism is debateable, as Marx (1994) also recognised the interconnectedness and hierarchical structure of classes in capitalist societies. A different disagreement with Marxism is evident; Bourdieu's emphasis on symbolic struggles over economic strugglesii. Bourdieu speaks of "objectivism" and "intellectualism" that, together with a narrow focus on economics "leads one to overlook the symbolic struggles that take place in different fields" (Bourdieu \& Thompson, 1991, p. 239).

In this respect, Bourdieu's concept of social space to some extent contradicts the traditional Marxist notion of classes as historically formed entities with specific roles and inherently antagonistic interests. For Bourdieu, the social space consists of a multitude of invisible relationships. Each position in this space is defined by its relative location and distance to other positions. This assumption to some degree implies a rather individualistic view of society as a conglomeration of atomised individuals in a hierarchical order. Bourdieu expresses this view explicitly: "From a scientific standpoint, what exists is not 'social classes' ... but rather a social space" (Bourdieu, 1987, p. 3). Nevertheless, Bourdieu acknowledges that similar positions in social space and the experience of similar living conditions and relative power(lessness) can bring people closer together and can lead to a potentially strong and potent group identity. The commonality of experience happens intrinsically (in terms of material conditions) and relationally (in terms of relative position to other members of society) (Bourdieu, 1987). Classes are, for Bourdieu, analytical constructs, "but constructs well-founded in reality" (Bourdieu, 1987, p. 5).

Classes therefore exist in Bourdieu's view not as actual groups; "What exists is a space of relations" (Bourdieu \& Thompson, 1991, p. 232) with varying proximity of the individuals inhabiting that space. Accordingly, classes can be constructed along different lines of demarcation. These theoretical classes are however not necessarily real classes. For Bourdieu, the defining aspect is what Marxists would call "class consciousness" and what Bourdieu describes as follows: "groups made of individuals united by the consciousness and the knowledge of their commonality of condition and ready to mobilise in pursuit of 
their common interest" (Bourdieu, 1987, p. 7). So structure alone does not make classes, they are always the result of a historical process that translates economic conditions and shared experience into a shared, class- or groupspecific perception of the social structure. Bourdieu speaks of a theoretical class as a "class on paper" (Bourdieu, 1987, p. 7) that transforms into a real class by the political process of "classmaking" (Bourdieu, 1987, p. 8). The parallels to the Marxist distinction between "class in itself" and "class for itself" (Marx, 1963, p. 173) are rather obvious, and also, in Bourdieu's concept classes are not constructed in a random fashion, but are "collectives having an economic and social base" (Bourdieu, 1987, p. 9).

To be clear, Bourdieu does not perceive social classes as material entities, but uses the term as a theoretical construct that can legitimately claim to describe large groups of people who share similar positions in social space and accordingly similar living conditions, potentially resulting in a shared understanding of the group's position and interests. Bourdieu and Marx appear to reach similar conclusions with regards to the shape of classes, but substantiate their claims rather differently. On a superficial level, Bourdieu agrees with the classic Marxist view that classes are interrelated and hierarchically structured. The nature of this relationship is however not necessarily based on their respective positions in the production process. If it is, it is in a rather indirect way. The same can be said about domination and exploitation; their existence is not disputed, but is not interpreted in a predominantly economic way. Bourdieu is less interested in the economic structures that define classes, but more in their political, cultural and psychological foundations and in the ways class inequalities are practically experienced and reproduced as well as challenged and resisted. This nexus, as well as the process of class-making and the individual and collective repercussions of (class) inequalities, are theorised in Bourdieu's habitus concept.

\section{The Habitus Concept ${ }^{\mathrm{iii}}$}

For Bourdieu, societal structures are partly upheld and reinforced through processes that can best be understood with reference to psychological concepts, or more precisely with the utilisation of the idea of an individual and collective unconscious. Bourdieu uses the term habitus to describe the unconscious aspects or, more specifically, the internalisation of societal structures. The habitus reflects the position of an individual or group in the class structure and at the same time refers to collective and individual practice that is shaped by the individual's or group's position in social space. Habitus therefore embodies the "indirect causal link between position in social space and practices" (Weininger, 2005 , p. 90). It therefore not only refers to attitudes, beliefs and concepts of self and the world, but also to individual and collective action and for Bourdieu these two spheres are closely linked. 
Bourdieu intends to explain how the "outer" becomes the "inner" and speaks of the "incorporation of the objective structures of the social space" (Bourdieu \& Thompson, 1991, p. 235). This happens largely on an unconscious level as social structures are usually not consciously analysed or verbally expressed by the individual. Bourdieu here refers to Goffman's (1951, p. 297) idea of the "sense of one's place" and the "practical mastery of the social structure" (Bourdieu and Thompson, 1991, p.235).

This "mastery" is acquired not predominantly through active reflexion or explicit tuition, but through experience. The individual experiences him/herself in social structures and power relations and derives their sense of place from this. The perception of the social world and the production of meaning are therefore structured; how the social world is perceived "beyond the directly visible attribute" (ibid.) is greatly influenced by one's position in the social space which is in turn informed by past (symbolic) struggles and characterised by a certain vagueness. The need to understand the historicity of both field and habitus is something we illustrate with contemporary examples in the section below.

The link between position and disposition is crucial in this context. Bourdieu does not suggest that a given position in social space concretely determines an individual's habitus, rather that the position in relationships of power relate to specific dispositions with regards to the habitus (Crossley, 2008). Positions (of power) tend to be closely related to more general life conditions and therefore Bourdieu see a strong link between position (in social space) and disposition (of the habitus).

The habitus also informs individual and collective practice and serves Bourdieu as a concept of practice that neither relies solely on objectivism (that understands action as mere reaction to circumstances), nor on subjectivism (that emphasises unmediated conscious intention) (Bourdieu \& Wacquant, 1992). As mentioned, Bourdieu is rather reluctant to speak of social groupings as classes and therefore it is questionable whether it is advisable to speak of a "class habitus" in a Bourdieusian sense. Nevertheless, habitus is a collective as much as an individual concept. When the habitus becomes objectified as lifestyle, there are clearly collective processes at play (Moore, 2008). The social aspects of the concept become apparent when lifestyles get categorised in a hierarchical order. This order reflects their origin in the social space as well as their proximity to the legitimate culture. Bourdieu's understanding of social theory is a rather pragmatic and practical one. Habitus, for him, describes not only intellectual aspects of classed existence, but also its practical manifestations. Theory is, for Bourdieu, a tool to come to terms with them. In the following, we briefly discuss a number of studies that attempt to apply the habitus concept to the contemporary social world.

Processes of internalisation are central to psychological research. Vygotsky (1987, p. 57) goes as far as stating that "internalisation of socially rooted and historically developed activities is the distinguishing feature of human psychology". If applied to social class, we would argue, there is a need to 
psychologically explore how the "sense of one's place" establishes itself and more specifically, how inequalities and political power are perceived and ultimately internalised. In the following we want to briefly portray research that aims to apply the dualism that makes the habitus concept a complex, yet valuable research tool.

\section{Habitus Inspired Research}

Research informed by Bourdieu's habitus concept confirms that class is a relevant category that people use to make sense of the world (e.g. Savage, 2001; Skeggs, 1997; Reay, 1998). However, these authors also found reluctance by some to identify themselves in class terms. Class is a very ambivalent, emotionally charged concept that is, in a wider sense, political, as well as loaded with meaning and normativity (Savage, 2001). Despite being rejected as a category and despite the difficulty to verbally define and express its essence, class is lived. Reay (1998) insists that the concept of class is used by people to locate themselves and others, and emphasises that class is not only a social, political and ultimately theoretical concept, class is "done", it is performed on a daily basis and influences attitudes and practice.

More recent research conducted in a contemporary UK context by Haylett (2003), Lawler (2004), Tyler (2008) and Walkerdine et al. (2001) analyses how habitus shapes subjectivity, but the aforementioned authors do so without neglecting the social anchoring of the concept. Haylett (2003) for instance describes the dialectical nature of habitus as produced by divisions of society whilst simultaneously reproducing those divisions. Class is, for her, as it is for Bourdieu, a "matter of embodied social practice" (Haylett, 2003, p. 62). Social inequalities are reflected in individuals and as Walkerdine et al. (2001) point out, this happens on a multitude of levels. Difference is produced and (generally involuntarily) displayed through accents, style, housing etc. and, importantly, people are often acutely aware of the hierarchy of these micro-distinctions. Walkerdine et al. (2001) make the point that as much as class is naturally a collective concept, in the understanding of their participants, (class related) classifications were made based on the characteristics of the individual person. Accordingly, it was the individual that was being rated and judged. And, as Tyler (2008) adds, this judgement is often emotionally mediated. Class distinctions become displaced and individualised on to the individual person who is "approved or disapproved, normalized or pathologized" (Lawler, 2004, p. 110). Through this process, the central social inequalities are realised in the individual; objective inequalities between large groups are translated into differences in individual behaviour and attitudes. As Reay (2005) demonstrates, internalised hierarchies have a strong emotional dimension in the sense that they are perceived as (potentially damaging) personal judgments that regulate normality. Value judgements tend to be morally loaded and therefore likely to inflict shame (Sayer 2005). Again, these judgements relate to the hierarchical class structure of a society, but tend to be made on an individual level. 
Looking at class from a Bourdieusian perspective clearly suggests a rather broad interpretation of the concept. Class forms identity way beyond conscious affiliations and political attitudes. Therefore, we prefer the term "class habitus" to the term "class identity" as the former points to a more comprehensive understanding of class. Habitus includes very relevant unconscious elements of classed being, and also examines the dialectical relation between the material reality and (unconsciously formed) attitudes. Bourdieu illustrates this nexus with the example of perceived limits and confined expectations. Through the process of internalisation "social divisions become principles of division" (Bourdieu, 1984, p. 471). The perception of the social world is structured by a mental structure that is itself greatly influenced by the (power) structure of the social world. Therefore, social realities, like the unequal distribution of power for example, appear natural or self-evident. In the context of the chosen example this means that the dominated social actor perceives her role as justified, or as Bourdieu puts it, the "embodiment of the objective laws" results in individuals "adjusting their expectations to their chances, defining themselves as the objective order defines them" (Bourdieu, 1984, p. 471).

This nexus can probably be most clearly analysed in educational contexts where it is not only the differences in cultural capital that influence outcomes, but also differences with regards to habitus. 'Educational aspiration' is however a very limited and ultimately not useful operationalization of educational habitus. In a Bourdieusian sense, the class-related differences in educational achievement mirror the social hierarchy for a number of reasons. The aforementioned 'sense of one's place' comes into play again. Whereas children of middle- and upperclass parents are equipped with a sense of entitlement and an expectation of educational success, their working-class peers would need to break with (internalised) collective expectations in order to match their aspirations (Nash, 2003). Reay (2005, p. 921), pointing to the affective aspects of upward mobility, speaks of "the emotional cost of becoming different". Bourdieu is however keen to point out that differences in the educational habitus are not solely a matter of attitude, values and emotional distress (and therefore open to psychological intervention or treatment), but to some degree a rational choice that reflects limited educational opportunities and takes the potentially limited benefits of higher education for working-class students into account. So again, Bourdieu sees the reproduction of inequality as an interplay of social structure, (collective) agency, and, crucially, the internalisation of inequality that makes social disparities appear natural.

This reasoning appears very much confirmed by the pieces of research alluded to above. "Knowing one's place" (within a hierarchical structure) is a theme that shows in most of the aforementioned studiesiv. Thinking "habitus" instead of "identity" brings into focus processes of domination and in particular their invisibility. However, it is important to note that "knowing one's place" and accepting the status quo as natural is not a pre-given, as the history of class conflict during the twentieth century will testify. Nevertheless, we wish to make 
the case that in the current epoch of shrinking social space and a marked decline of class consciousness, in the Western world at least, habitus itself has been transformed. $v$

As abstract and overly complex as it might appear, habitus is a concept that research can successfully fill with life. After all, social class is a lived concept. Using the concept of habitus can help to appreciate these complexities and grasp the (inseparable) individual and social dimensions of class. In order to bring such abstract concepts alive, in the next section we briefly detail some contemporary socio-political factors and how they can affect the habitus, or in other words, how the outside gets inside.

\section{Habitus in a Shrinking Social Space ${ }^{\mathrm{vi}}$}

As noted above, perception of the social world is structured by a mental structure that is itself greatly influenced by the (power) structure of the social world, and this process can lead to an acceptance of limits and confine expectations. Often, such a process is disguised under apparently benign or progressive policies. For example, much has been written about the disciplinary nature of professions such as psychiatry, psychology and social work to label, categorise and control those seen as deviant from the norm. However, such a process not only creates an object, such as the "schizophrenic", it can also create a subject who thinks, feels and acts in the "appropriate" way for a "mental patient" (e.g. Foucault, 1967; Scheff, 1984; Rose, 1999). vii

The impact of relations of power can be subtle and are arguably more readily acceptable as a result. For example, the concept of "empowerment" is frequently cited as the goal of social policy and related social and psychological interventions. One government publication by the UK New Labour government in 2009, which contained a foreword by the then Prime Minister Gordon Brown and an introduction by then Secretary of State for Communities and Local Government Hazel Blears, mentioned empowerment thirty-six times (CLG, 2008), whilst the current UK Prime Minister David Cameron has represented empowering people as being 'a natural part of a Conservative approach to government' (Conservatives, 2009, online).

Empowerment is a term that is utilised both by the political left and the political right, although the intent behind the term is different. For the Left empowerment is represented as a cornerstone of political resistance, for the Right it refers to economic and entrepreneurial actors. Nevertheless both perspectives share the same political strategy which is a desire "to act upon others by getting them to act in their own interest" (Cruikshank, 1999, p.68).

However, despite its current ubiquity the actual term 'empowerment' is a relatively recent addition to contemporary social policy discourse. For example, in Lukes' (1974) classic discussion of power the term empowerment does not 
appear in the index. It was 1986 before the term appeared in a peer-reviewed original article in either Critical Social Policy (Beuret and Stoker, 1986) or the British Journal of Social Work (Ryan, 1986). This is interesting given our contention, detailed below, that it was the mid-1980s that saw the demise of the working class as a political force capable of exercising its collective power. This mainstream academic and political adoption of empowerment differed from its more radical usage within past social movements where the term tended to refer to the need to challenge the dominant political (and personal) structures that were held responsible for oppressive social relations - for example see Collins (1991) in relation to empowerment and Black feminism and Kankowski (1997) in relation to Deaf empowerment. As it moved to the mainstream there was more of a focus on individual, personal empowerment that required the guidance of a professional such as a therapist, counsellor or advisor.

Adams (2008) argues that empowerment can be seen as 'the capacity of individuals, groups and/or communities to take control of their circumstances, exercise power and achieve their own goals, and the processes by which, individually and collectively, they are able to help themselves and others to maximize the quality of their lives' (p.17). In this respect 'empowerment' can be seen as a relatively benign term, a way of helping people gain increased power to organise their affairs and achieve their goals and desires.

However, there is often a failure to acknowledge the way the powerful can influence the wants, desires and values of the powerless. In this respect, the contemporary notion of empowerment as a process that allows people to have more control over their lives can prove illusory. In reality, it can operate as a mechanism for drawing people into participating in processes and decisions over which they have little control. As Langan (2002) notes,

Parents are said to be empowered by being invited to attend child protection case conferences; they thus become complicit in measures of state intervention in their family life decided on by professionals and the police. Applicants for community care are empowered by the fact that their designated social worker is also the manager of a devolved budget which is limited by criteria quite independent of the applicant's needs. Too often, empowerment means reconciling people to being powerless.

In other words, the power that is given is bound within certain parameters, and these can lead to a lowering of expectations as well as being predicated on the client ultimately being submissive to those who, in reality, wield power. In a Bourdieusian sense this is reflected in a habitus that internalises experienced powerlessness and that inclines the agent "to make a virtue of necessity, that is, to refuse what is anyway refused" (Bourdieu, 1977, p. 77).

So, whilst the concept of empowerment ostensibly seeks to challenge the sense of "knowing one's place", in effect it can merely reproduce the parameters of place and the scope of action within a changed, but still limited habitus. 
The rise to prominence of the rhetoric of empowerment did not go unnoticed or uncontested. Indeed the term had its critics even as it was first becoming established. By the early 1990s some had noticed how the term had become something of a buzz-word that littered the mission statements of health, welfare and education services (Gomm, 1993). Humphries (1996) noted how its mention directly or by implication had become 'de rigueur in articles, books and political statements' and that it had 'become a key objective in the training of professionals of all kinds, particularly the caring professions' (p.1). Such a situation led Humphries to ask, and attempt to answer, the question of why the discourse of empowerment had become so dominant at this historical moment. She highlights the political struggles around class, feminism and anti-racism of the 1970s and 1980s and the rise and fall of bureaucratic and proceduralist strategies to combat inequality which differed from the more radical perspectives. The latter was more concerned with empowerment as being something that emerged through individual and collective action, the former involving a more top-down approach to the alleviation of individual and societal problems. Increasingly the more radical understanding of empowerment was appropriated within more mainstream political discourse and realigned with consumer culture and a more individualised notion of how to achieve empowerment. viii

In similar vein, Langan (2002) points out that during the 1970 s radical activists had a commitment to the "self-activity" of the working class. In such a climate of collective working class action the notion of philanthropy implied by the bestowal of power by professionals on the working class was not particularly resonant; the belief was that members of the working class were capable of organising themselves, of gaining power from below by virtue of their collective strength, not having it sprinkled onto them from above like confetti. In this respect,

the rise of the concept of empowerment and its institutionalisation within social work theory and practice is reflective of both the decline of working class collective power and the changing conception of 'empowerment'; from something to be taken, by force if necessary, to something to be handed down by the state.

(McLaughlin, forthcoming)

Operating in a political climate in which ideology was seen as discredited and working class collective power was waning, the scope for critiques of structural oppression and collective political action was limited. These changes helped create a space for the terminology of empowerment to grow unencumbered by the baggage of "misguided" past political ideologies or practices. In other words, habitus itself was transformed.

\section{Grounding the Habitus in psychological research}


In this section we will discuss how the habitus concept can be useful for psychological explorations of social class. First, we want to demonstrate how the habitus concept is, to a great degree, founded psychologically (and is therefore very compatible with psychological research), and second, we intend to discuss how the habitus concept can enrich psychological research by addressing a number of blind spots of mainstream psychology.

As alluded to above, Bourdieu is critical of the division of labour between sociology and psychology, and his work can be seen as an attempt to bridge the gap between these two disciplines. The habitus concept in particular aims to challenge the dichotomy between "inner" and "outer" or "individual" and "social", but does so without damaging the analytical integrity of structure and agency (Maton, 2008). Bourdieu accepts that, for analytical purposes at least, structure and agency can be treated as separate entities, but encourages social research to relate the two terms to each other. Accordingly, it makes little sense to talk about the habitus in isolation, i.e. without talking about the relating social field at the same time. Doing so would "fetishize" (Maton, 2008, p. 61) the habitus and ultimately reduce it to a rather detached, superficial and ahistorical analysis of (class-specific) habits.

This superficial and ahistorical tendency can be illustrated by the problematic way much psychological research deals with the problem of "work stress". Often, the individual is ranked against pre-determined indicators of "stress", and the higher the score the more stress they are said to be suffering (e.g. HSE, online). Such an approach is not only problematic from the point of view of psychiatric legitimacy, more importantly for our purposes, it merely engages with the present habitus to formulate a diagnosis. It fails to locate habitus historically within a changed social space in which the articulation of conflict and distress along class lines has changed markedly.

In the United Kingdom at least, whilst the working class may exist, it has to a large degree been marginalised. Numerous industrial defeats, perhaps most notably that of the 1984-85 miners' strike, have influenced the way in which social space, in this particular case the workplace and industrial relations, are conceptualised. For example, the increasing failure, due to various factors, of collective working class action to win industrial disputes led to a change in tactics and role for trade unions. Today, there is likely to be less emphasis on the collective strength of the workforce and more focus on the individual weakness of the worker. Rather than be encouraged to take industrial action, for example by going on strike, the worker is more likely to be encouraged, often by their union representative, to take industrial inaction by going off sick due to suffering from "work stress" (Wainwright and Calnan, 2002). This is not to suggest that the worker is feigning illness, on the contrary, their subjective distress can be all too real. Rather, in Bourdeusian terms it is to provide an account of one way in which the outside gets inside. 
A useful way of conceptualising the emergence of the subject from his surroundings is that of the "triple helix self" by which Wainwright and Calnan seek to extend Marx's (1852) observation that "Men make their own history, but they do not make it just as they please; they do not make it under circumstances chosen by themselves, but under circumstances directly encountered, given and transmuted from the past" (p.1). In the triple helix self, the three strands of the helix represent the natural environment, discourse and corporeality respectively.

Mind or subjectivity emerges from the helix as the three points spiral around each other across the life course. As well as illustrating the formation of the self at a particular point in time (the head of the helix), the model also reveals the biographical-historical dimensions of the self (the tail of the helix), as historically specific environmental conditions and discursive formations interact with corporeality across time. It is important to recognize that the tail of the helix predates the birth of the individual because corporeality (in the form of genetic material), and obviously discourse and the external environment, already exist (and already interact) before the emergence of the individual self.

(Wainwright and Calnan, 2002, pp.85-86)

In relation to workplace conflict the discursive and material changes lead to a changed habitus, with a corresponding influence on subjectivity (McLaughlin, 2008). For example, as Wainwright and Calnan (2002) note, the concept of 'stress' has influenced a change in both terminological and subjective understandings of workplace relations whereby traditional problems around oppressive management or exploitation are rearticulated within a health and safety framework, the former becoming 'bullying' or 'harassment', the latter 'excessive demands' or 'unreasonable pressure'.

Using habitus as a descriptive rather than a relational term is in our opinion problematic for mainly three reasons. First, there is the danger that habitus is merely assumed or appropriated, simply overlaying data, instead of making the concept work in specific contexts (Reay, 2004). Habitus is not to be naturalised or essentialised but to be understood as existing in relation to specific fields and (power) structures.

Second, there is the related danger of putting an overly strong emphasis on the unconscious element of habitus and thereby ignoring its cognitive aspects. Doing so marginalises conscious agency and renders oppression virtually impossible to escape. Political resistance is turned into a solely therapeutic problem. Third, and again related to tendencies of naturalisation and essentialisation of habitus, there is the danger of a misuse of the habitus concept in the sense that systematically contradictory political and economic interests are reified as individual differences in terms of character or personality. Bourdieu has warned against the possibility of that specific misuse of his theory (Zander, 2010) and pointed out that this interpretation could function as a misguided explanation for poverty and would effectively reverse the relation between 
habitus and power. Differences in habitus are the result of social inequalities not their cause.

So, instead of an ahistorical and/or individual or indeed meso level analysis of the individual's dispositions, Bourdieu suggests a relational mode of thinking that links visible empirical practice to underlying structural and structuring principles. Therefore, using the concept of habitus as a research tool necessarily encourages a rather broad focus that relates such things as individual behaviour and attitudes to social structures (Reay, 2004). To this we would add the need for a historically oriented approach. Hence, habitus can be seen as a connecting link between sociological and psychological questions. Bourdieu (1988, p. 782) sums up his ambition to counter the division of sociology and psychology thus:

I believe that true scientific theory and practice must overcome this opposition by integrating into a single model the analysis of the experience of social agents and the analysis of the objective structures that make this experience possible.

With the habitus concept, Bourdieu offers a method to put this demand into practice. Applying the habitus as a research tool to the aforementioned domains of empowerment and work stress, can help to historically locate, recontextualise and critically further debates around these terms. This applies to the formulation of the respective problems and can also point towards potential solutions. Habitus as a method reintroduces the historical, social and political dimensions of empowerment and work stress. This is urgently needed as both concepts, as we have shown, nowadays tend to be negotiated on a predominantly individual level. Habitus as a theoretical concept and as a method can help to reconcile agency and structure. Habitus as a method can point to the relationship between individual and collective agency and more specifically to the already discussed interdependency of alleged individual responsibility and the lack of collective agency that are crucial with regards to both work stress and empowerment.

Furthermore, the habitus concept brings into focus the political dimension and power structures of these areas. Habitus as a method can help to examine domination as everyday practice and to analyse how power is reproduced as well as resisted on an individual as well as on a collective level. Habitus is a method to analyse the dominance of dominant groups and the domination of subordinate groups (Reay, 1995).

Finally, the historic dimensions and significance of the historicity of the discussed domains can be explored by utilising habitus. Habitus as a concept tries to address how the complex interplay between past and present translates into individual and collective consciousness (Bourdieu, 1977).

Of course, the actual difficulty lies in the practical application and operationalization of a concept as complex and, at times, elusive as the habitus. This is particularly true if one intends to follow Bourdieu's demand not to 
essentialise habitus and to relate its specific contents to the related fields and wider social and political frameworks.

Given its complexity and psychoanalytical foundation, it might come as a surprise that Bourdieu uses habitus as a method in a rather conventional manner. He suggests to focus on the (interview-generated) narrative as, for him, the place of analysis has to be the actual, concrete narrative (Couldry, 2005). Conclusions regarding the habitus can be derived from those narratives. Bourdieu is very clear however, that this focus on individual narratives does not restrict social research to only exploring individualistic points of view. Quite the opposite, Bourdieu is of the opinion that individual narratives can express structural conditions:

This explains the way that narratives about the most 'personal' difficulties, the apparently most subjective tensions and contradictions, frequently articulate the deepest structures of the social world and their contradictions.

(Bourdieu \& Ferguson, 1999, p. 511).

This is particularly true for people in precarious positions who develop an understanding of the objective contradictions that "have them in their grasp" (Bourdieu \& Ferguson, 1999, p. 511). So with regards to work stress, this means that narratives of (supposedly) individual suffering can point to wider historical developments and political and structural conditions like inequality, power struggles, exploitation and alienation.

As shown above, the habitus concept draws on psychological ideas and we would argue that there are a number of reasons to support Zander's (2001) claim that habitus "cannot be founded convincingly without considering psychological contributions" (pp.1-2). Bourdieu clearly builds on the psychoanalytical idea of the unconscious. Social constraints are not usually evident to the individual. On the contrary, they tend to be perceived as normal and therefore not open to conscious analysis. Shared, but nevertheless class and gender specific "assumptions that 'go without saying' determine the limits of the doable and the thinkable" (Maton, 2008, p. 59). Habitus can consequently not be seen as a concept solely referring to conscious, intellectual aspects of human existence. Habitus should rather be understood as "embodied", as a way of acting as well as thinking and feeling. Hence, habitus informs practice not in a predominantly cognitive, rational and straightforward fashion, but as implicit knowledge of what is appropriate, or as Bourdieu himself puts it, as a "feel for the game" (Bourdieu, 1990, p. 61) or the aforementioned 'sense of one's place'. Often, this 'sense of one's place' can be reinforced through processes that are ostensibly about challenging the subordinated social status of social, mostly working class, actors.

Processes of internalisation are of central relevance for the habitus concept. Bourdieu argues that social and economic constraints enter the individual's consciousness in the shape of such things as rules, constraints, taste and 
conflict. These are related to the individual's position in the social hierarchy, and as alluded to above, positions in social space cause relatively stable dispositions in the individual. This nexus is not to be interpreted as a mechanistic and straightforward process, but as a complex and emotionally charged interplay. Bourdieu puts a strong emphasis on the practical character of classed existence and points out that dispositions can be derived from practice without entering discourse or consciousness (Zander, 2010). This unconscious element in the reproduction of power is played out on an individual as well as on a collective level and is reflected in the duality of the habitus concept. As we have alluded to above, the hierarchical order of the social informs attitudes, behaviours and emotions in a very practical and not necessary conscious and cognitive way. Skeggs (1997) exemplifies how implicit knowledge about one's place in the social hierarchy unconsciously informs a person's sense of belonging and affinity, and more specifically how participants in her study (working-class girls) felt out of place in a high-priced department store due to feeling a sense of unease in a setting they felt they did not have a right to be in. This sense of feeling out of place is aggravated by the lack of a positively loaded female working class position in the UK context.

\section{Conclusion}

Bourdieu speaks of "socio-analysis" by which he is referring to the strong collective element in the historically formed unconscious (Bourdieu \& Ferguson, 1999, p. 628). Analogous to psychoanalysis, he sees a potentially therapeutic function in the process of self-analysis. By bringing one's place in the social world and the social conditions that shape the social hierarchy into consciousness, they are no longer perceived as the natural order of things but are opened up to critique.

These are themes psychological research can clearly relate to and explore further. With the habitus concept, Bourdieu discusses areas like taste, aspiration and the formation of gender and class-specific experiences that are certainly of interest to psychologically informed research. What makes the habitus concept so valuable is the thematisation of the inextricable connection of the individual and the social dimension of these matters. As El-Mafaalani and Wirtz (2011) argue, from a methodological point of view habitus is very compatible with psychological research as it aims to objectively explore the positions of the individual in the social world. Bourdieu tries to formulate systematic functional contexts on the basis of descriptions of individual experiences and action. Furthermore, habitus, applied in a Bourdieusian sense, always incorporates political aspects and relates supposedly neutral or apolitical circumstances and developments to processes of power.

This however happens on a very fundamental level and it might therefore be somewhat short-sighted to state that habitus is helpful to uncover 
distinguishable aspects of power in social interactions and conditions (McNay, 2008). However, with regards to subject formation, power in a Bourdieusian sense is not one aspect among many others, but constitutive of the whole process. The same goes for the involved psychological dynamics; power structures are not only reinforced by psychological dynamics but shape them on a very fundamental level. Habitus as a concept therefore can counter discourses that "depoliticise oppression" (McNay, 2008, p. 10) and help to put oppression back on the map and to re-politicise it.

In similar vein, the habitus concept can, in our opinion, contribute to uncover and to critically discuss possible blind spots of psychological research. Exploring "blind spots" in contemporary mainstream psychology with regards to social class is from our point of view best approached by discussing underlying, often implicit, ideological assumptions that inform mainstream psychological research and that push the aforementioned attempts to utilise habitus as a research tool to the fringes of the discipline. In other words, we would argue that much mainstream psychology tends to avoid dealing with classed inequalities as social class as a concept stands in conflict with an individualised understanding of human nature. Due to a preoccupation with (supposedly) individualistic motivations for behaviour, collective and social aspects take a back seat. Parker $(2007$, p. 33$)$ argues that "there are always intriguing blind spots where some features [of human nature] are taken for granted" and that therefore psychology "remains trapped within its own horizon". The difficulties of mainstream psychology to relate to structural inequalities are, according to Parker (2007), expressed in the assumption of a statistical normal distribution, the bell curve, that orders people along pre-set dimensions and defines normality and abnormality as percentages, as statistical variations.

Rose (1996), in a similar vein, argues that the individualised understanding of human existence is ideologically founded and also ideological in its effects as 'the self' functions according to Rose (1996, p. 127) as a "regulatory idea". In this world view social issues are reframed as individual responsibilities. Again the political nature of empowerment comes to the fore and is reflected in the language of political discourse when unemployed people are referred to as (supposedly empowered) 'job seekers' and homeless people turned into 'rough sleepers' (Rose 1996). Social problems are translated into individual challenges and comprehended as solvable by self-betterment. Rose (1999) demonstrates how this ideology empowers psychology as a discipline and vastly increases its scope and influence. According to this critique, mainstream psychology is affirmative in its effects as it reproduces the image of the autonomous, morally responsible citizen and uses techniques that make this citizen interested in their own government. Structural inequalities, which are at the core of the habitus concept, are therefore difficult to reconcile with a world view that appears to inform mainstream psychology, not least because they would to some degree curtail or call into questions the remit of the discipline. 
Nevertheless, as we have shown, there are no principle incompatibilities that would make the interpretation and utilisation of habitus in psychological research per se problematic. On the contrary, the application of the habitus concept in psychological research contexts could help to explore how objective (power) structures enter subjectivity. Internalisation and embodiment cannot just be assumed or taken for granted, but have to be critically discussed with regards to tensions, contradictions and possibilities for resistance. Accordingly, psychological (and psychoanalytical) insights can help to explore the processes that lead to the reproduction of power. Habitus is a notoriously vague and elusive concept and given the amount of work it has to do in Bourdieu's theory this is not a surprise. It is however very possible to apply the habitus concept to the real world and to use it as a formidable tool to grasp the complexity of the social world. Due to its foundations in psychological theory, habitus as method is very compatible with psychological explorations of social class.

\section{References}

Adams, R. (2008) Empowerment, Participation and Social Work (4 ${ }^{\text {th }}$ ed), Hampshire: Palgrave.

Althusser, L. (1971) Lenin and Philosophy and Other Essays, New York: Monthly Review Press.

Beuret, K. \& Stoker, G. (1986) 'The Labour Party and Neighbourhood Decentralisation: Flirtation or commitment? Critical Social Policy,6 (17), 4-22.

Bourdieu, P. (1977). Outline of a theory of practice. Cambridge ; New York: Cambridge University Press.

Bourdieu, P. (1984). Distinction : a social critique of the judgement of taste. London: Routledge.

Bourdieu, P. (1987). What Makes a Social Class? On The Theoretical and Practical Existence Of Groups. Berkeley Journal of Sociology, 32, 1-17.

Bourdieu, P. (1988). Vive la Crise! For heterodoxy in social science. Theory and Society, 19(5), 773-788.

Bourdieu, P. (1990). In other words : essays towards a reflexive sociology. Stanford, Calif.: Stanford University Press.

Bourdieu, P., \& Ferguson, P. P. (1999). The weight of the world : social suffering in contemporary society. Cambridge: Polity Press.

Bourdieu, P., \& Thompson, J. B. (1991). Language and symbolic power. Cambridge, Mass.: Harvard University Press.

Bourdieu, P., \& Wacquant, L. J. D. (1992). An invitation to reflexive sociology. Chicago: University of Chicago Press.

CLG (Communities and Local Government) (2008) Communities in control: Real people, real power. London: HMSO, www.communities.gov.uk/documents/communities/pdf/886045.pdf

Conservatives (2009) It's time to transfer power from the central state to local people.

www.conservatives.com/News/News_stories/2009/02/Its_time_to_transfer_ power_from_the_central_state_to_local_people.aspx 
Couldry, N. (2005). The Individual Point of View: Learning from Bourdieu's The Weight of the World. Cultural Studies Critical Methodologies, 5(3), 354372.

Crossley, N. (2008). Social Class. In M. Grenfell (Ed.), Pierre Bourdieu key concepts. Stocksfield: Acumen.

Cruikshank, B. (1999). The Will to Empower: Democratic citizens and other subjects, New York: Cornell University Press.

Dumais, S. A. (2002). Cultural Capital, Gender and School Success: The Role of Habitus. Sociology of Education, 75(1), 44-68.

El-Mafaalani, A., \& Wirtz, S. (2011). Is the habitus concept psychological? Pierre Bourdieu and interpretative psychology. Journal für Psychologie, 19(1), 11.

Foucault, M. (1967). Madness and Civilisation: A History of Insanity in the Age of Reason, London: Tavistock.

Friedman, P. K. (2009) Ethical Hegemony. Rethinking Marxism, 21 (3), 355-365 Goffman, E. (1951). Symbols of Class Status. The British Journal of Sociology, 2(4), 294-304.

Gomm, R. (1993). Issues of Power and Social Welfare. In Walmsley, J., Reynold, J. Shakespeare, P And Woolfe, R. (eds.) Health, welfare and practic: Reflecting on roles and relationships. London: Sage

Gramsci, A., Hoare, Q., \& Nowell-Smith, G. (1971). Selections from the prison notebooks of Antonio Gramsci. London,: Lawrence \& Wishart.

Haylett, C. (2003). Culture, class and urban policy: Reconsidering equality. Antipode, 35(1), 55-73.

Collins, P. H. (1991) Black Feminist Thought: Knowledge, Consciousness, and the Politics of Empowerment, London: Routledge.

HSE (Health and Safety Executive) (no date) HSE Management Standards Indicator Tool, http://www.hse.gov.uk/stress/standards/pdfs/indicatortool.pdf (accessed 28/3/14)

Hume, M. (2014). The biggest load of "General Strike" hype since the last lot. Spiked, http://www.spiked-online.com/newsite/article/the-biggest-load-ofgeneral-strike-hype-since-the-last-lot/15353 (accessed 10/8/14)

Humphries, B. (1996). Contradictions in the culture of empowerment. In Humphries, B. (ed) Critical perspectives on Empowerment. Birmingham: Venture Press

\section{Jankowski, K.A. (1997) Deaf Empowerment: Emergence, struggle and rhetoric, Washington: Gallaudet University Press.}

Langan, M. (2002). Radical Social Work. In Adams, R., Dominelli, L. And Payne, M. Social Work: $\quad$ Themes, Issues and Critical Debates, (second edition),Basingstoke: Macmillan.

Lawler, S. (2004). Rules of engagement: Habitus, power and resistance. In L. Adkins \& B. Skeggs (Eds.), Feminism after Bourdieu (pp. 110 - 128). Oxford, UK ; Malden, MA Blackwell Publishing,.

Lizardo, O. (2004). The Cognitive Origins of Bourdieu's Habitus. Journal for the Theory of Social Behaviour, 34(4), 375-401.

Lizardo, O. (2009). Is a "special psychology" of practice possible? From values and attitudes to embodied dispositions. Theory \& Psychology, 19(6), 713727. 
Lukes, S. (1974). Power: A radical view ( $2^{\text {nd }}$ ed. $)$, Basingstoke: Palgrave.

Maton, K. (2008). Habitus. In M. Grenfell (Ed.), Pierre Bourdieu key concepts (pp. 49 - 65). Stocksfield: Acumen.

Marx, K. (1852) The Eighteenth Brumaire of Louis Napoleon in Marx, K. and Engels, F. (1979) Collected Works, vol. 11, London: Lawrence and Wishart.

Marx, K. (1963) The poverty of philosophy. New York,: International Publishers.

Marx, K., Engels, F., \& Arthur, C. J. (1994). The German ideology. London,: Lawrence \& Wishart.

McLaughlin, K. (2014 forthcoming)). Politics as Social Work in the United Kingdom: The micromanagement of behaviour in the new millenium. In G. Palattiyil, D. Sidhva and M. Chakrabarti (Eds.), Social Work in a Global Context: Issues and challenges, London, Routledge.

McNay, L. (2008). Against recognition. Cambridge: Polity.

McRobbie, A. (2009). The Aftermath of Feminism: Gender, culture and social change, London: Sage

Moore, R. (2008). Capital. In M. Grenfell (Ed.), Pierre Bourdieu key concepts (pp. 101 - 117). Stocksfield: Acumen.

Nash, R. (2003). Social explanation and socialization: on Bourdieu and the structure, disposition,

\section{practice scheme. The Sociological Review 51(1) 43-62}

Parker (2007). Revolution in Psychology - Alienation to Emancipation. London: Pluto Press

Reay, D. (1995). 'They Employ Cleaners to Do that': habitus in the primary classroom. British Journal of Sociology of Education, 16(3), 353-371. doi: $10.1080 / 0142569950160305$

Reay, D. (1998). Rethinking social class: qualitative perspectives on class and gender. Sociology-the Journal of the British Sociological Association, 32(2), 259-275.

Reay, D. (2004). "It's All Becoming a Habitus": Beyond the Habitual Use of Habitus in Educational Research. British Journal of Sociology of Education, 25(4), 431-444.

Reay (2005). Beyond Consciousness? The Psychic Landscape of Social Class.

Rose 1990 Sociology, 39(5): 911-928

Rose, N. (1996) Identity, Genealogy, History. In: Hall, S. \& du Gay, P. (eds.) Questions of Cultural Identity. London: Sage

Rose, N. (1999). Governing the Soul. $2^{\text {nd }}$ ed. London: Free Association Books Ryan, P.J. (1986). The Contribution of Formal and Informal Systems of Intervention to the Alleviation of Depression in Young Mothers. British Journal of Social Work. 16, 71-82.

Savage, M. (2001). Ordinary, ambivalent and defensive: Class identities in the northwest of England. Sociology-the Journal of the British Sociological Association, 35(4), 875-894.

Sayer, A. (2005). Class, Moral Worth and Recognition. Sociology-the Journal of the British Sociological Association, 39(5), 947-963.

Scheff, T. (1984). Being Mentally III: A Sociological Theory $\left(2^{\text {nd }}\right.$ ed). Chicago: Aldine.

Skeggs, B. (1997). Formations of class and gender : becoming respectable. London ; Thousand Oaks, Calif.: SAGE.

Stam, H. J. (2009). Habitus, Psychology, and Ethnography: Introduction to the Special Section. Theory \& Psychology, 19(6), 707-711. 
Tyler, I. (2008). "Chav Mum Chav Scum". FEMINIST MEDIA STUDIES, 8(1), 17-34.

Vygotsky (1987), L.S. The collected works of L.S. Vygotsky. Vol. 1 Problems of general psychology: including the volume thinking and speech. New York: Plenum

Wainwright, D. and Calnan, M. (2002). Work Stress: The Making of a Modern Epidemic. Buckingham: Open University Press.

Walkerdine, V., Lucey, H., \& Melody, J. (2001). Growing up girl : psychosocial explorations of gender and class. New York: New York University Press.

Weininger, E. B. (2005). Foundations of Pierre Bourdieu's class analysis. In E. O. Wright (Ed.), Approaches to class analysis (pp. 82 - 118). Cambridge, UK ; New York: Cambridge University Press.

Zander, M. (2010). Under protection of the unconsciousness. Approaches to a psychological foundation of the habitus concept in the works of Pierre Bourdieu. Journal für Psychologie, 18(1), 1-19. 
i This critique is political in nature not in the sense that it necessarily produces political demands, but political in a sense that it problematizes structural inequalities and their repercussions.

ii Several Marxist thinkers have developed the analysis of the relation between the economic and the symbolic order. For example, see Friedman (2009) for an evaluation of the links between Gramsci's conception of hegemony and Bourdieu's concept of habitus.

iii Bourdieu was not the first to refer to habitus, Thomas Aquinas used the term in the thirteenth century to refer to the stable dispositions that people acquire throughout their lives (Kerr, 2009).

iv As mentioned, these studies were set in the UK and therefore the findings are to some degree specific to contemporary social, cultural and political circumstances in the UK. Class conflict in other historical and geographical contexts will have produced different understandings of social order and one's place in it.

$v$ The decline of class consciousness is a result of myriad factors. There were significant working class defeats during the 1980s, the defeat of the year long miners' strike of 1984-85 being the most high-profile example). A variety of anti-trade union legislation was also introduced which severely curtailed the use of spontaneous industrial action, limited the number of pickets and banned secondary picketing (although from a more radical perspective the demand would have been for action irrespective of state approval). In addition, the rise and institutionalisation of identity politics helped to sideline class as the main vehicle through which to locate the self and achieve social change.

vi We use the term 'shrinking social space' to refer to the process whereby social and political issues are frequently reduced to interpersonal psychological issues disconnected from any wider socio-political analysis. 
vii This is not to imply that such a process is not resisted. Indeed, there have been many instances of both individual and collective struggle against the power of the psydisciplines (e.g. see Crossley, 2006).

viii For an example of this in relation post-feminism, 'girl-power' and consumer culture see McRobbie (2009). 